\title{
Manufacturing technology for implementing geological disposal: electroforming of copper canisters
}

\author{
T. Hernandez-Selva ${ }^{1,2,3, *}$, D. L. Engelberg ${ }^{1,3}$, F. Scenini ${ }^{1,4}$, D. Fox ${ }^{2}$ and A. McClusky ${ }^{2}$ \\ 1 Materials Performance Centre, School of Materials, The University of Manchester, Manchester M13 9PL, UK \\ 2 BEP Surface Technologies Ltd, Eton Hill Road, Radcliffe, Manchester M26 2XT, UK \\ 3 Research Centre for Radwaste and Decommissioning, The University of Manchester, Manchester M13 9PL, UK \\ 4 Nuclear Advanced Manufacturing Centre, The University of Manchester, Manchester M13 9PL, UK
}

\section{ABSTRACT}

The existing capability and current development needs for implementing electroforming as a viable manufacturing process to produce copper cylinders with dimensions comparable to the Swedish KBS-3 design are discussed. Large freestanding copper cylinders can be produced readily, but there is a need to address challenges associated with controlling the electro-deposition process to conform to compositional and mechanical requirements of the copper layers produced. The methodology to optimize the manufacturing process, based on a study of key parameters, such as the effects of electrolyte additives on grain size and the chemical composition of electroformed layers, is described here. Possible ways to introduce a robust manufacturing route are also presented.

KeYwords: nuclear wastes, deep geological repository, KBS-3 copper canister, electroforming, electroplating.

\section{Introduction}

THE concept for the UK's inventory of high-level radioactive waste (HLW) is to implement deep geological disposal (Department of Energy \& Climate Change, 2014; Padovani, 2014; Nuclear Decommissioning Authority, 2014). One of the proposed disposal options is to encapsulate HLW and spent fuel (SF) in thick-walled copper canisters, the KBS-3 design, proposed by the Swedish Nuclear Fuel and Waste Management Company, SKB (Svensk Kärnbränslehantering $\mathrm{AB}$, 2011). Countries such as Finland (Posiva), Hungary (PURAM), Lithuania (Lithuanian Energy Institute) and Slovenia (ARAO) have adopted the Swedish design (Posiva Oy, 2013a,b; Lithuanian Energy

* E-mail: tomas.hernandez-selva@manchester.ac.uk; ths@bep-st.com

DOI: $10.1180 /$ minmag.2015.079.6.27
Institute, 2006; ARAO, 2009), whereas the Nuclear Waste Management Organization (NWMO) of Canada is focusing its research on thick-walled steel containers coated with $3 \mathrm{~mm}$ of electroplated copper (Keech et al., 2014).

The KBS-3 design specifies an outer high-purity (oxygen-free) copper canister for corrosion resistance supported by a cast-iron insert, providing rigidity and mechanical strength. The elemental specification for the copper canister restricts the oxygen content to some tens of ppm, hydrogen to $<0.6 \mathrm{ppm}$, and sulfur to $<12 \mathrm{ppm}$, whilst requiring the phosphorus content to be between 30 and 70 ppm (Svensk Kärnbränslehantering AB, 2010). Currently, based on these stringent compositional limitations, canisters can only be manufactured using high-purity copper via extrusion and forming processes (Svensk Kärnbränslehantering AB, 2004).

The concept reported here explores electroforming as an alternative manufacturing route for copper shells. Electroforming, in this case, is carried
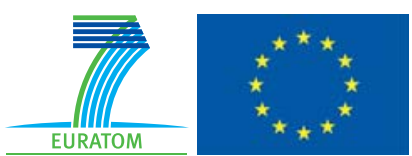

The publication of this research has been funded by the European Union's European Atomic Energy Community's (Euratom) Seventh Framework programme FP7 (2007-2013) under grant agreements $n^{\circ} 249396$, SecIGD, and $n^{\circ} 323260$, SecIGD2. 
out by electroplating copper onto a mandrel that acts solely as a support during the production and which is later removed from the copper shell. Compared with extrusion-based manufacturing processes, this methodology is more energy efficient and environmentally friendly, allows better surface finishes with greater strength, removes the need for machining the inside of the copper shells and enables the production of a thinner wall thickness for standalone copper shells. In addition to these manufacturing benefits, the electroplating process can be controlled to achieve a uniform grain-size distribution, which overcomes the problem of low detectability of defects using ultrasonic testing encountered in extruded products (Posiva Oy, 2013c; Svensk Kärnbränslehantering $\mathrm{AB}, 2014)$. A feasibility study (BEP Surface Technologies Ltd, 2009) has demonstrated the possibility of electroforming copper shells of reduced length but the same diameter as the KBS-3 canister, and revealed that the technology to manufacture large-scale components exists. However, challenges associated with meeting the stringent compositional requirements were highlighted. The latest approach, reported here, focuses therefore, on tuning the manufacturing process.

The aim of the work reported here is to provide insight into the development of electroforming for the production of copper cylinders in order to comply with KBS-3 copper-canister requirements. Research is directed towards optimizing the electroplating technology, in particular to (1) identify sources of impurities in the copper layer and ultimately control them via the electroplating process, (2) understanding the effect of operating parameters on large-scale copper electroplating, and (3) to implement manufacturing technology for the production of copper-canister prototypes via electroforming.

\section{Experimental}

Copper was electroplated in small batches from an acidic copper-sulfate electrolyte, containing copper sulfate $\left(\mathrm{CuSO}_{4} \cdot 5 \mathrm{H}_{2} \mathrm{O}\right)$, sulfuric acid $\left(\mathrm{H}_{2} \mathrm{SO}_{4}\right)$, and sodium chloride $(\mathrm{NaCl})$. A fresh electrolyte was prepared for each plating trial, employing analyticalgrade chemicals (AnalaR NORMAPUR ${ }^{\mathbb{R}}$ ) and demineralized water. Copper plating additives were obtained from commercial suppliers. Four different commercially available additives were investigated, referred to hereafter as additives 1-4 (Table 1). The glassware for preparing the copper electrolyte was cleaned with a potassium permanganate $\left(\mathrm{KMnO}_{4}\right)$ solution to remove any organic contaminant. Before using the glassware the potassium permanganate was removed, and the glassware rinsed with water and hydrogen peroxide $\left(\mathrm{H}_{2} \mathrm{O}_{2}\right)$ to neutralize any remaining permanganate residue. A power supply operated in the galvano-static mode was used to control the current density for the electroplating process.

For plating trials conducted under deoxygenated conditions, nitrogen gas (technical, grade 5.0) was bubbled through the solution for $30 \mathrm{~min}$ prior to starting the electroplating process and continued during the electroplating process to prevent oxygen re-dissolution.

The surface tension of plating solutions provides information about the solubility of gases in an electrolyte (Weissenborn and Pugh, 1996) and the property of gas-bubble development at solid surfaces (Gabe, 1996). The surface tension of the electroplating solutions was measured with a stalagmometer and a hydrometer, using Tate's law (Tate, 1864). The stalagmometer had a volume of $5 \mathrm{ml}$ (Kocour Company). The hydrometer was $1.10-1.15 \pm 0.002^{\circ}$ S.G. (specific gravity) (Brannan \& Sons Ltd, Cumbria, UK).

Electroplating trials were carried out to produce small rectangular copper samples with typical dimensions of $40 \mathrm{~mm} \times 30 \mathrm{~mm} \times 0.5 \mathrm{~mm}(1 \times \mathrm{w} \times \mathrm{d})$. In order to facilitate the removal of the electroplated copper layers after deposition, stainless steeltype $316 \mathrm{~L}$ sheets were used as a base material. An electroplating cell with $1000 \mathrm{ml}$ of electrolyte volume was used, and the temperature of the

TABLE 1. Oxygen content and surface tension of copper samples electroplated from electrolytes with different additives. The copper electrolyte contained $150 \mathrm{~g} / \mathrm{l}$ $\mathrm{CuSO}_{4} \cdot 5 \mathrm{H}_{2} \mathrm{O}, 60 \mathrm{~g} / \mathrm{H} \mathrm{H}_{2} \mathrm{SO}_{4}, 100 \mathrm{ppm} \mathrm{NaCl}$. Parts per million (ppm) have been expressed as $\mathrm{mg}$ of oxygen per kg of sample.

\begin{tabular}{lll}
\hline Sample & $\begin{array}{l}\text { Oxygen } \\
(\mathrm{ppm})\end{array}$ & $\begin{array}{l}\text { Surface tension } \\
(\text { dynes} / \mathrm{cm})\end{array}$ \\
\hline Additive-free & 41 & 76.7 \\
$\begin{array}{l}\text { Deoxygenated } \\
\quad \text { solution }\end{array}$ & 13 & - \\
Additive $1^{*}$ & 9 & 74.1 \\
Additive $2^{*}$ & 180 & 70.1 \\
Additive 3* & 25 & 65.2 \\
Additive 4* & 7 & 57.2 \\
\end{tabular}

*Additives provided by Atotech, Schlotter, Enthone and MacDermid, respectively. 
electrolyte controlled using an immersion heater and a K-type thermocouple connected to a temperature controller with a solid-state relay. The temperature was kept constant within $\pm 0.1^{\circ} \mathrm{C}$ using a thermostat. Electroplating experiments were performed at $6 \mathrm{~A} / \mathrm{dm}^{2}$ and $30^{\circ} \mathrm{C}$. The material used for the anode was phosphorized deoxidized (PDO) copper. After electroplating, all electroplated samples were rinsed with deionized water, dried in hot air and then kept in sealed polypropylene plastic bags until further analysis. The copper layers removed were analysed for their hydrogen and oxygen content using the LECO ONH 836 Inert Gas Fusion Infrared and Thermal Conductivity Detection technique. Measurement of carbon concentration depth profiles were carried out using Glow Discharge Optical Emission Spectroscopy (GD-OES), employing a Horiba GD Profiler.

Following initial laboratory trials, a 1001 tank was employed to study the effect of larger-component geometry on the electroplating system. The cathode was a steel mandrel placed horizontally on top of the tank, which was connected via a driving belt to a motor to provide a constant rotation speed during the deposition process. The copper electrolyte was cleaned continuously by recirculating the solution through a $25 \mu \mathrm{m}$ filter. Small cylindrical copper shells with dimensions of $10 \mathrm{~cm}$ inner diameter, $20 \mathrm{~cm}$ long and $1 \mathrm{~cm}$ thick were produced with this process. Results obtained from analysis of samples produced with the 1001 electroplating set-up were compared with those obtained at the laboratory scale to study the possible effects of scaling up the plating process, with the overarching goal to produce KBS-3 type copper shells.

\section{Results and discussion}

\section{Existing capability and knowledge transfer}

The technology for producing electroformed copper cylinders already exists, and copper chill rolls with dimensions comparable with the proposed KBS-3 canisters are readily manufactured for the packaging industry (e.g. BEP Surface Technologies, www.bep-st.com). However, for producing copper chill rolls there are no constraints on the compositional requirements and oxygen concentrations, with typical layer compositions ranging from 10 's to 100 's of ppm of oxygen, depending on the electroplating conditions and parameters.

A typical copper chill roll with dimensions of $1 \mathrm{~m}$ diameter, $2.5 \mathrm{~m}$ long and $16 \mathrm{~mm}$ thick is shown in Fig. 1. The typical time taken to produce a $16 \mathrm{~mm}$ thick electroformed deposit is $8-10$ days, depending on the current density applied. A steel mandrel is employed as the cathode for the plating process and phosphorized deoxidized copper in titanium baskets as anodes. The copper shell is released from the mandrel, and finally mounted on a lathe to carry out grinding and polishing operations to achieve required surface finishes. Depending on the application, nickel and/or chrome layers can also be electroplated on top of the cylindrical copper shell, often employed in the
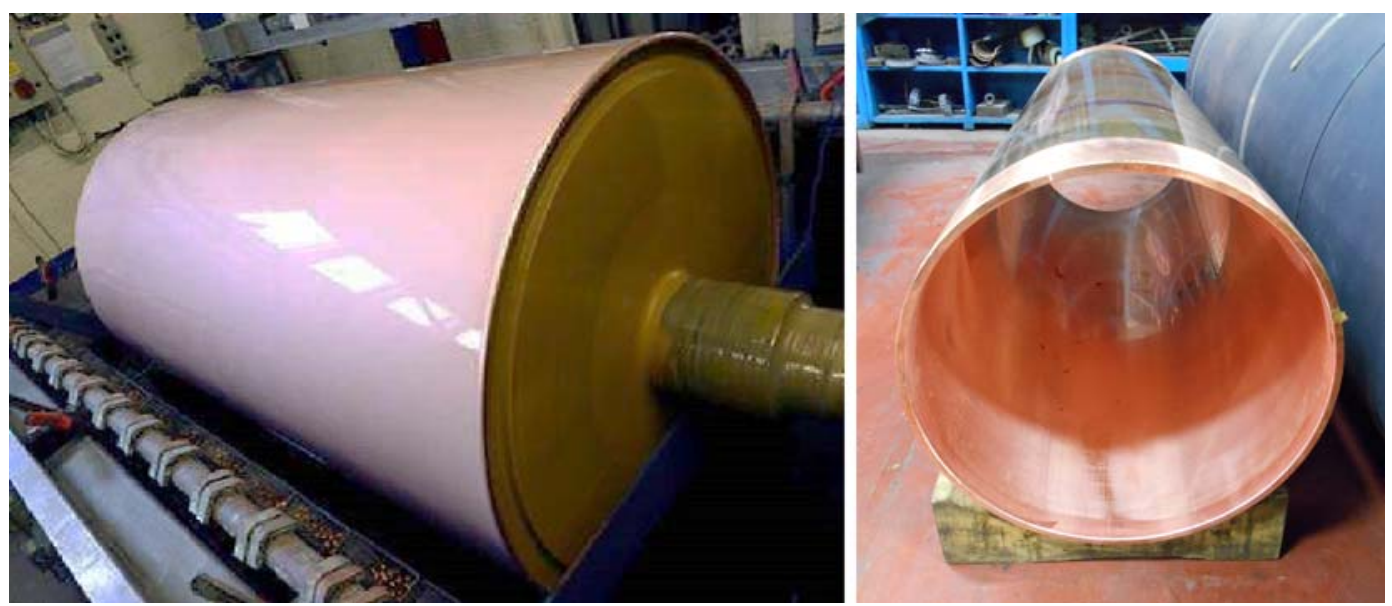

FIG. 1. Electroformed copper chill roll during manufacture (left) and copper shell produced by electroforming (right), with typical dimensions of $1 \mathrm{~m}$ diameter, $2.5 \mathrm{~m}$ long and $16 \mathrm{~mm}$ wall thickness. 
laminating industry. This demonstrates that the technology to produce large, freestanding copper cylinders by electroforming already exists.

\section{Optimization and control of chemical composition and grain size}

A very important requirement associated with the KBS-3 standards is the necessity to control the chemical composition of the electro-deposited layer. Elemental analysis of the layers was therefore carried out on laboratory-scale samples to optimize the process. Two examples are shown below to demonstrate how electro-deposited copper can be tailored as a function of the operating parameter (current density) and electrolyte composition (additives). The amount of impurities and the microstructure of the electroplated copper are studied as a function of the presence of acid copper-plating additives in the electrolyte.

Table 1 shows the oxygen content of copper layers for different additives, together with surface tension results of the copper electrolytes. These additives are employed to optimize layer properties and to improve process characteristics, such as levelling or throwing power. The presence of an additive may affect the final properties of the electroplated copper by modifying the microstructure, or by incorporation in the electroplated copper layer. In the same context, additives could also have also a strong effect on the surface tension. Surface tension is the property of the surface of a liquid that allows it to resist an external force, revealing the wettability of the surface. This has important implications for the hydrogen evolution that inevitably occurs during the cathodic plating process. A decrease in surface tension results in an increase in wettability with smaller break-off diameter of bubbles (Vogt and Balzer, 2005).

In the present study, only minor changes in surface tension were noted for the different additives (Table 1). The fact that additive-free solution has comparable surface tension to those of additives 1 and 2 suggests that the surface tension has no direct effect on the resulting oxygen content of the electro-deposited layer. The difference obtained between additive $2(180 \mathrm{ppm})$ and additives 1 and $4(<10 \mathrm{ppm})$ also suggests that careful selection of additives certainly contributes to the final impurity content of the deposited layer. Interestingly, it was also shown that by deoxygenating an additive-free solution, the oxygen content of the layer decreased significantly. This, in turn, suggested that that dissolved oxygen in solution may be a source or at least a contributing factor to influence the oxygen content in the deposited layer.

These results can be rationalized by considering how the acid copper additives are categorized into three groups: brighteners, leveller and carriers. Brighteners (accelerators) and levellers (inhibitors) act by reducing the electrodeposition on areas with high current densities. They enhance deposition on areas with less current density, improving the levelling of the deposit, and reducing the grain size (Kruglikov et al., 1965). Carriers (suppressors/ inhibitors) stabilize the diffusion layer at the anodes and cathode by controlling the diffusion of the copper ions (Vaduva et al., 2011). Regarding the chemistry of additives, brighteners are typically made of organic sulfide compounds, polysulfides and thio-ethers; levellers from quaternary nitrogen compounds; and carriers from long-chain organic molecules, such as polyethylene glycol and polyalkylene glycol (Schlesinger and Paunovic, 2011). Polyethylene glycol and ethers are widely employed as surfactants for different applications (Chen and Gao, 2007; Schwuger, 1973). However, the oxygen contents in samples plated with different additives show no correlations with surface-tension measurements (Table 1). This may be explained by considering the differences between the reactions involving hydrogen and oxygen. Hydrogen is always reduced as a secondary reaction during metal plating and can remain adsorbed in its atomic form on the surface of the cathode, and therefore diffuse into the electroplated material, or recombine to form molecular hydrogen. This seems not to be applicable for oxygen where the secondary cathodic reaction does not involve a gas phase, only dissolved oxygen, and occurs at a marginal rate with respect to hydrogen evolution.

It is also widely accepted that additives such as levellers work by adsorbing onto the copper surface (Stoychev et al., 1978; Hope et al., 1995; Vereecken et al., 2005). This was confirmed with experiments employing an electrochemical quartz microbalance showing that polyethylene glycol adsorbs at the cathode (Kelly and West, 1998). Therefore, as additives are close to the surface where the electrodeposition takes place it is more likely that they are incorporated into the deposited layer and therefore increase the organic content of the electroplated layer. Although carbon is not mentioned directly as a specific impurity, the overall KBS-3 specification defines not more than $0.01 \%$ (i.e. $100 \mathrm{ppm}$ ) of total impurities. Therefore, in order to investigate the role of additives on the 


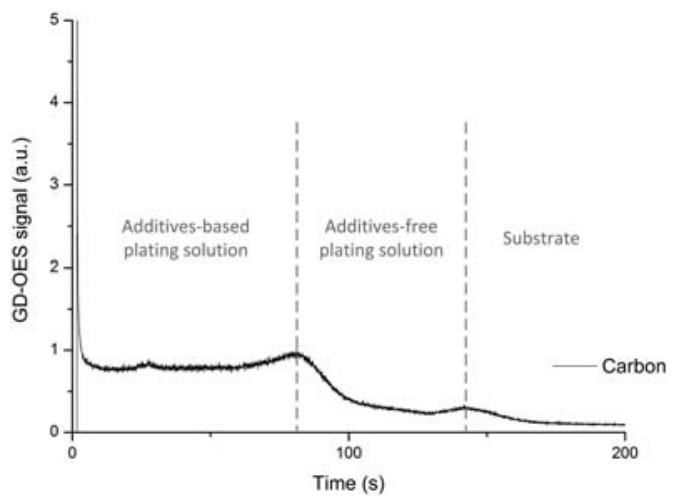

FIG. 2. GD-OES profile of a multilayer sample; top layer electroplated from additive-containing solution (additive 3 ) and bottom layer electroplated from additive-free solution.

carbon concentration, an electroplated layer was partly produced in an additive-free solution and then followed by electroplating in electrolyte containing additive 3. Both layers were produced at $3 \mathrm{~A} / \mathrm{dm}^{2}$, with the additive-free layer and additive-containing layer electroplated for $40 \mathrm{~min}$ and $85 \mathrm{~min}$, resulting in layers $27 \mu \mathrm{m}$ and $57 \mu \mathrm{m}$ thick, respectively. This dual-layer was analysed through its depth using GD-OES to obtain a measure of the carbon content. The depth profile results reported in Fig. 2 show a strong decrease in the carbon content observed, corresponding to the transition to the copper layer without additives. These results corroborate the hypothesis that certain additives work by adsorption at the cathode during the electrodeposition process (Stangl et al., 2005; Moriyama et al., 2004).

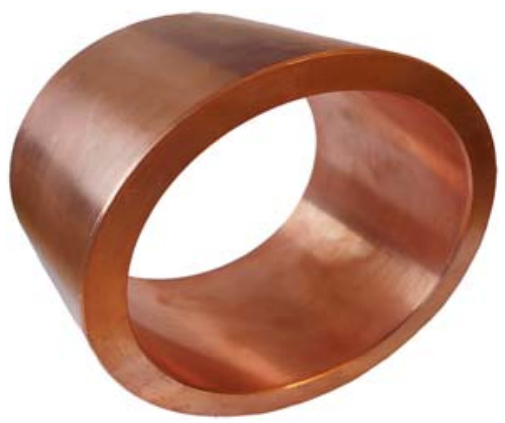

FIG. 4. Copper shell $(10 \mathrm{~cm}$ inner diameter, $20 \mathrm{~cm}$ long, $1 \mathrm{~cm}$ thick) electroformed on the $100 \mathrm{~L}$ tank.

The effect of additives on the cross-sectional evolution of the electroplated microstructure is noticeable. Figure 3 compares the grain size for a sample electroplated with additive 3 (Fig. $3 a$ ) with a sample electroplated from an additive-free solution (Fig. 3b). For identical plating conditions $\left(6 \mathrm{~A} / \mathrm{dm}^{2}, \quad 30^{\circ} \mathrm{C}, \quad 150 \mathrm{~g} / 1 \quad \mathrm{CuSO}_{4} \cdot 5 \mathrm{H}_{2} \mathrm{O}, \quad 60 \mathrm{~g} / 1\right.$ $\mathrm{H}_{2} \mathrm{SO}_{4}$ and $100 \mathrm{ppm} \mathrm{NaCl}$ ) the grain size of the sample electroplated from the additive-based electrolyte appears to be more equi-axed, compared to the columnar grains in the sample without additives. However, the deposit in Fig. 3a seems to possess a dual grain size, with a number of very large grains surrounded by clusters of smaller grains. The large differences in the microstructure and grain morphology are not reflected in differences in the measured surface tension (Table 1).
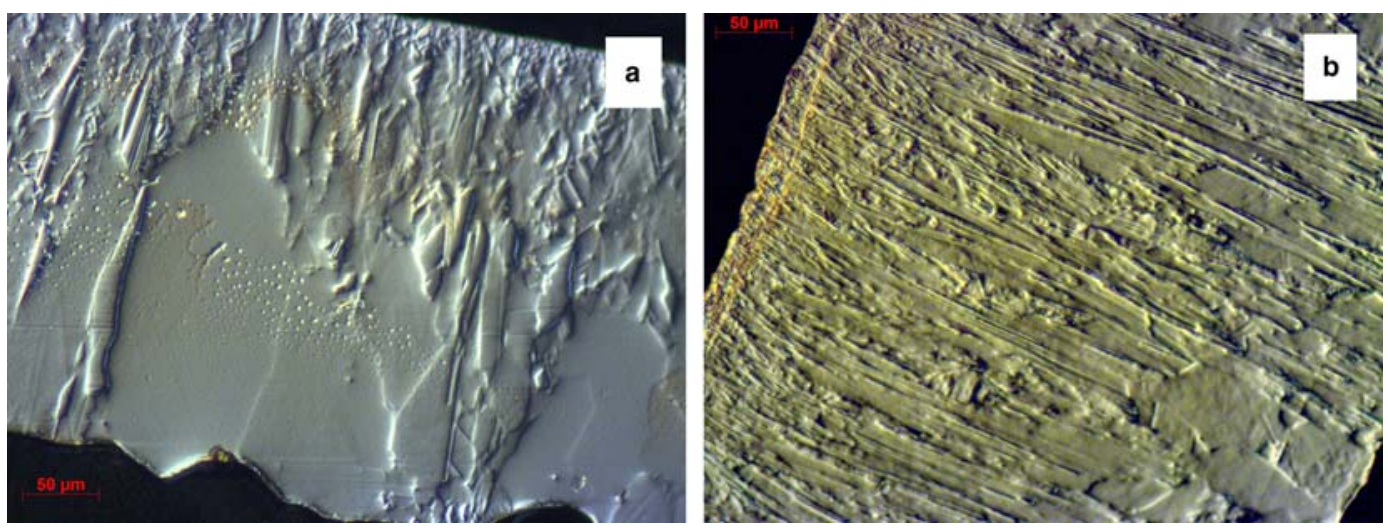

FIG. 3. Typical effect of additives on grain size and grain morphology of electroplated samples with: (a) solutioncontaining additive 3 ; and $(b)$ additive-free solution. 


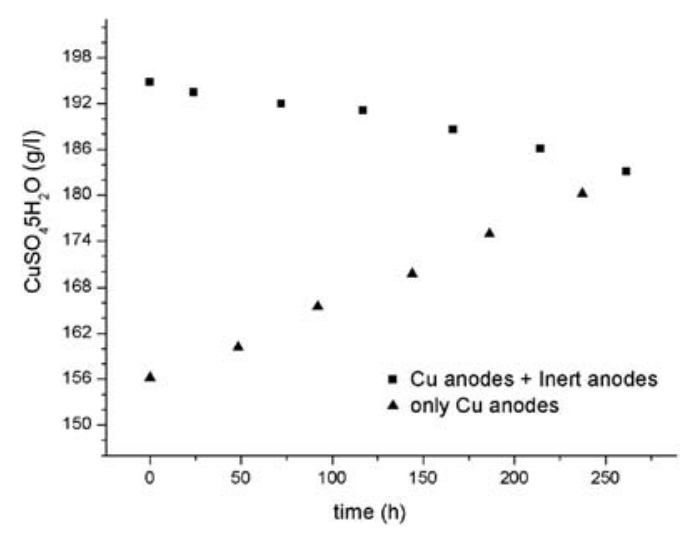

FIG. 5. Variation of copper sulfate concentration during plating, with (ム) copper anodes only, and (-) copper anodes in conjunction with inert anodes.

\section{Challenges to control prototype development}

One of the main challenges associated with production of full-scale copper shells is the up-scaling from laboratory-scale coupons whilst maintaining full control over the operational parameters. Prototype development was carried out on medium-scale plating in a larger tank $(100 \mathrm{~L})$ to obtain copper shells with typical dimensions of $10 \mathrm{~cm}$ inner diameter, $20 \mathrm{~cm}$ length, and $1(+) \mathrm{cm}$ thickness, shown in Fig. 4. The main problem associated with up-scaling the process arises when plating is carried out over a long time period as this affects the copper sulfate concentration in the electrolyte. The copper sulfate concentration during the plating process was monitored by iodometric titration and appears to increase when only copper anodes are employed (Fig. 5). This can be explained considering that, although the electroplating efficiency of acid copper plating is close to $100 \%$, i.e. almost all the current is employed to reduce the copper ions in solution, the copper dissolution has a chemical (Gregory and Riddiford, 1960) as well as an electrochemical (Rashkov and Vuchkov, 1981) component.

By inserting inert anodes in conjunction with copper anodes it is possible to control and even correct this trend, as shown in Fig. 5. In fact, in this case, an excessive inert anode area was purposely employed to prove this concept. Thus, by selecting an appropriate ratio between the area of copper anodes and that of inert anodes, the copper sulfate concentration can be kept constant during plating. Due to the variation in the copper-sulfate concentrations, and consequently the sulfuric-acid concentration, online monitoring of the concentration of the constituents on the plating solution is essential to control the plating processes.

Cyclic voltammetry was employed to determinate the concentration of redox species in the copper electroplating solution by adopting the well-

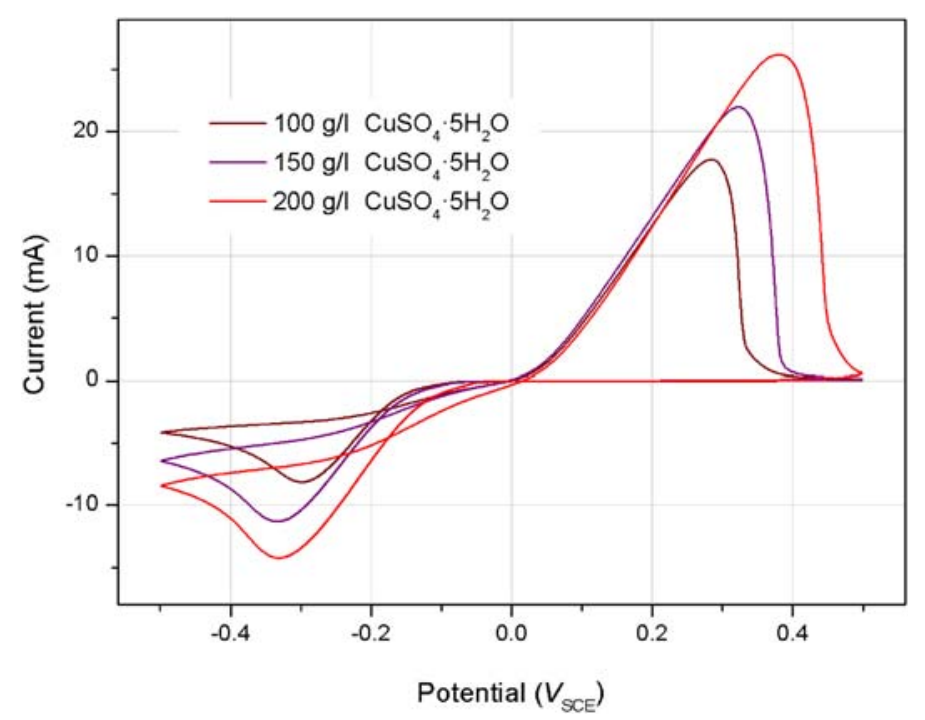

FIG. 6. Cyclic voltammogram of an acid copper-plating process with different copper sulfate concentrations. $65 \mathrm{~g} / \mathrm{l}$ $\mathrm{H}_{2} \mathrm{SO}_{4}, 100 \mathrm{ppm} \mathrm{NaCl} .30^{\circ} \mathrm{C} .50 \mathrm{mV} / \mathrm{s}$. $\mathrm{CuSO}_{4} \cdot 5 \mathrm{H}_{2} \mathrm{O}$ concentrations: $100 \mathrm{~g} / 1$ (brown), $150 \mathrm{~g} / 1$ (blue), $200 \mathrm{~g} / \mathrm{l}$ (red). 


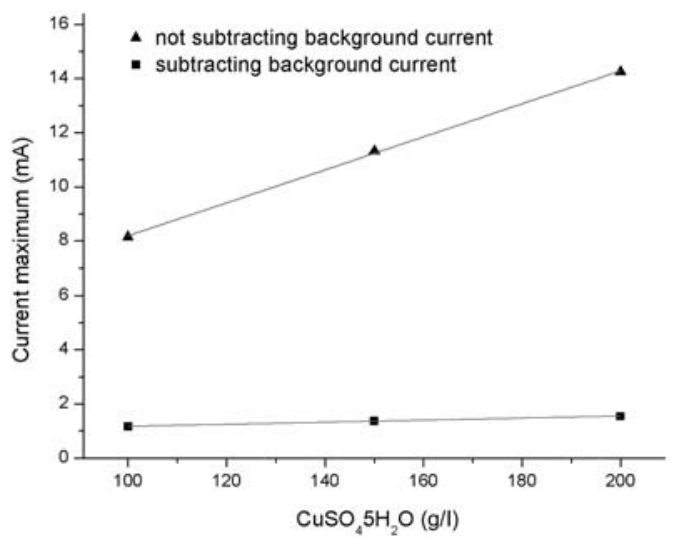

FIG. 7. Linear regressions for the relationships $(\mathrm{g} / \mathrm{l}$ $\mathrm{CuSO}_{4} \cdot 5 \mathrm{H}_{2} \mathrm{O}$ vs. current maximums) obtained from voltammograms shown in Fig. 6, with (घ) and without

(ム) subtracting the background current.

established Randles-Sevcik approach (Raoof et al., 2010; Jiang et al., 2012; Bard and Faulkner, 2000). The cyclic voltammograms obtained from solutions with different copper sulfate concentrations is shown in Fig. 6. The Randles-Sevcik relationship can then be used to describe the electrolyte concentration as a function of measured maximum current. If cyclic voltammetry is performed at the same temperature and scan rate, and it is assumed that the diffusion coefficient is constant within the concentration investigated, it is possible to determine the concentration of the solution from the maximum current obtained from the cyclic voltammograms (Scenini et al., 2014).

The current maxima obtained from the cathodic sweep of the voltammograms in Fig. 6 are summarized in Fig. 7. These values have been obtained with and without subtracting the background current of each individual voltammogram, and the data have been fitted to a linear regression. This analysis confirmed a linear relationship of the copper concentration $\left(\mathrm{g} / \mathrm{l} \quad \mathrm{CuSO}_{4} \cdot 5 \mathrm{H}_{2} \mathrm{O}\right)$ with current maxima, resulting in a coefficient of determination $\left(\mathrm{R}^{2}\right)$ of 0.9995 . This indicates that the hypothesis of constant diffusion coefficient is met within the concentration range studied and therefore the technique can be employed to determine the $\mathrm{CuSO}_{4} \cdot 5 \mathrm{H}_{2} \mathrm{O}$ concentration during prolonged electroplating.

\section{Conclusions}

Manufacturing technology for the production of large, free-standing copper cylinders exists already.
The main challenges lie in exerting tight control over elemental compositions and the resulting mechanical properties of the electroformed layers, which can be achieved by controlling the type of copper electrolyte additive employed. A robust manufacturing process is currently under development for controlling the electro-forming process to ensure optimized performance characteristics of the copper layers produced.

\section{Acknowledgment}

Financial support for this research was provided by the Innovate UK (formerly Technology Strategy Board TSB) under the Knowledge Transfer Partnership No. 009047.

\section{References}

ARAO (2009) Revised Reference Scenario for Geological Disposal Facility in Hard Rock with Cost Estimation for its Implementation. Report ARAO-03-00-014004-2, Ljubljana (Slovenia).

Bard, A.J. and Faulkner, L.R. (2000) Electrochemical Methods: Fundamentals and Applications, 2nd edition. John Wiley \& Sons, New York.

BEP Surface Technologies (2009) Research Project NWDA 09/0058. Unpublished. Funded by the Nuclear Decommissioning Authority (NDA) of the UK, 2009.

Chen, Z. and Gao, L. (2007) Synthesis and magnetic properties of $\mathrm{CoFe}_{2} \mathrm{O}_{4}$ nanoparticles by using PEG as surfactant additive. Materials Science and Engineering $B, \mathbf{1 4 1}, 82-86$.

Department of Energy \& Climate Change (2014) Implementing Geological Disposal - A framework for the long-term management of higher activity radioactive waste. URN 14D/235, London.

Gabe, D.R. (1996) The role of hydrogen in metal electrodeposition processes. Journal of Applied Electrochemistry, 27, 908-915.

Gregory, D.P. and Riddiford, A.C. (1960) Dissolution of copper in sulfuric acid solutions. Journal of the Electrochemical Society, 107, 950-956.

Hope, G., Brown, G., Schweinsberg, D., Shimizu, K. and Kobayashi, K. (1995) Observations of inclusions of polymeric additives in copper electrodeposits by transmission electron microscopy. Journal of Applied Electrochemistry, 25, 890-894.

Jiang, D., Xiang, G., Liu, C., Yu, J., Liu, L. and Pu, X. (2012) Development of a cyclic voltammetry method for DNA electrochemical detection on microfluidic gene chip. International Journal of Electrochemical Science, 7, 10607-10619. 
Keech, P.G., Vo, P., Ramamurthy, S., Chen, J., Jacklin, R. and Shoesmith, D.W. (2014) Design and development of copper coatings for long term storage of used nuclear fuel. Corrosion Engineering, Science and Technology, 49, 425-430.

Kelly, J.J. and West, A.C. (1998) Copper deposition in the presence of polyethylene glycol. I. Quartz crystal microbalance study. Journal of Electrochemical Society, 145, 3472-3476.

Kruglikov, S.S., Kudriavtsev, N.T., Vorobiova, G.F. and Antonov, A.Y.A. (1965) On the mechanism of levelling by addition agents in electrodeposition of metals. Electrochimica Acta, 10, 253-261.

Lithuanian Energy Institute (2006) Generic repository concept for rbmk-1500 spent nuclear fuel disposal in crystalline rocks in Lithuania. International topical meeting TOPSEAL 2006 - Reference No. 38099786 , Kaunas (Lithuania).

Moriyama, M., Konishi, S., Tsukimoto, S. and Murakami, M. (2004) Effect of organic additives on formation and growth behavior of micro-void in electroplating copper films. Materials Transactions, 45, 3172-3176.

Nuclear Decommissioning Authority (2014) Geological Disposal - Science \& Technology Plan. NDA Report no. NDA/RWM/121, Oxford, UK.

Padovani, C. (2014) Overview of UK research on the durability of container materials for radioactive wastes. Corrosion Engineering, Science and Technology, 49, 402-409.

Posiva Oy (2013a) Safety case for the disposal of spent nuclear fuel at Olkiluoto - models and data for the repository system 2012. Report POSIVA 2013-01, Eurajoki, Finland.

Posiva Oy (2013b) KBS-3H Complementary Studies, 2008-2010. Report POSIVA 2013-03, Eurajoki, Finland.

Posiva Oy (2013c) Inspection of disposal canisters components. Report POSIVA 2012-35, Eurajoki, Finland.

Raoof, J., Ojani, R. and Mohammadpour, Z. (2010) Electrocatalytic oxidation and voltammetric determination of hydrazine by $1,1^{\prime}$-Ferrocenedicarboxylic acid at glassy carbon electrode. International Journal of Electrochemical Science, 5, 177-188.

Rashkov, St. and Vuchkov, L. (1981) The kinetics and mechanism of the anodic dissolution of phosphoruscontaining copper in bright copper plating electrolytes. Surface Technology, 14, 309-321.

Scenini, F., Palumbo, G., Stevens, N., Cook, A. and Banks, A. (2014) Investigation of the role of electrokinetic effects in corrosion deposit formation. Corrosion Science, 87, 71-79.

Schlesinger, M. and Paunovic, M. (2011) Modern Electroplating, $5^{\text {th }}$ edition. John Wiley \& Sons, New York.

Schwuger, M.J. (1973) Mechanism of interaction between ionic surfactants and polyglycol ethers in water. Journal of Colloid and Interface Science, 43, 491-498.

Stangl, M., Acker, J., Dittel, V., Gruner, W., Hoffmann, V. and Wetzig, K. (2005) Characterization of electroplated copper self-annealing with investigations focused on incorporated impurities. Microelectronic Engineering, 82, 189-195.

Stoychev, D., Vitanova, I., Rashkov, S. and Vitanov, T. (1978) Adsorption of substances acting as brighteners in the electrolytic deposition of copper. Surface Technology, 7, 427-432.

Svensk Kärnbränslehantering AB (2004) Status report, canister fabrication. Technical Report TR-04-23, Stockholm, Sweden.

Svensk Kärnbränslehantering AB (2010) Design, production and initial state of the canister. Technical report TR-10-14, Stockholm, Sweden.

Svensk Kärnbränslehantering AB (2011) Long-term safety for the final repository for spent nuclear fuel at Forsmark - Main report of the SR-Site project. Technical Report TR 11-01, Stockholm, Sweden.

Svensk Kärnbränslehantering AB (2014) Attenuation dependent detectability at ultrasonic inspection of copper. Public Report 1411328, Stockholm, Sweden.

Tate, T. (1864) On the magnitude of a drop of liquid formed under different circumstances. Philosophical Magazine, 27, 176-180.

Vaduva, C.C., Vaszilcsin, N. and Kellenberger, A. (2011) Effect of aromatic amines on the diffusion layer thickness during the copper electrodeposition from acid bath. Chemical Bulletin of Politehnica University of Timisoara, 56, 75-80.

Vereecken, P.M., Binstead, R.A., Deligianni, H. and Andricacos, P.C. (2005) The chemistry of additives in damascene copper plating. IBM Journal of Research and Development, 49, 3-18.

Vogt, H. and Balzer, R.J. (2005) The bubble coverage of gas-evolving electrodes in stagnant electrolytes. Electrochimica Acta, 50, 2073-2079.

Weissenborn, P.K. and Pugh, R.J. (1996) Surface tension of aqueous solutions of electrolytes: relationship with ion hydration, oxygen solubility, and bubble coalescence. Journal of Colloid and Interface Science, 184, $550-563$. 